\title{
LEGISLATIVE CONTROL OF JUDICIAL BEHAVIOR
}

\author{
Carr L. Shiplex*
}

I

\section{INTRODUCTION}

In recent years there has developed a "civilian review" syndrome in our society, evidencing a distrust of and dissatisfaction with the performance of elected and appointed government officials. It has led to legislative efforts to establish various types of review boards to oversee the work of police, executive officers, and federal agencies. As the nation has grown, government has expanded until one out of every six citizens is now a government employee, exercising some degree of administrative power over the lives and property of his fellow citizens. The federal government alone has over $23 / 4$ million employees, and only the President, Vice President, roo Senators and 435 members of the House of Representatives are elected. The rest are appointed under civil service laws and regulations assuring them a tenure of employment almost equivalent to life and good behavior. ${ }^{1}$ Even private employees of government contractors may be protected against dismissal. ${ }^{2}$ Citizen uneasiness with the independence of this vast bureaucracy stimulates legislative efforts to regain control one way or another.

The federal judiciary has not escaped efforts of reformers to interpose some kind of legislative control over judicial behavior. Early in 1966, Senator Joseph C. Tydings, Chairman of the Subcommittee on Improvements in Judicial Machinery, commenced an investigation of "the availability of and need for procedures to govern removal, retirement, and disciplining of unfit Federal judges." ment, Senator Tydings said:

The purpose of these hearings is to determine whether the Federal judiciary has the necessary statutory tools to police its own house fairly, efficiently, and if not, to explore the possibility of drafting and introducing remedial legislation. ${ }^{4}$

This presumes, of course, that statutory regulation of the judiciary is both desirable and constitutionally permissible. The purpose of this article is to indicate that this suggestion fails on both counts. Specifically, it will be shown that the men

* (Mr. Shipley, a former Special Assistant United States Attorney General and Adjunct Professor at the American University, is presently in private practice in Washington, D.C. He filed an amicts brief for the petitioner in Chandler v. Judicial Council of the Tenth Circuit, 398 U.S. 74 (r970)-Ed.)

${ }_{5}$ U.S.C. $\$ \$ 2005,4304$ (I964); United States v. Lovett, 382 U.S. 303 (I946); Bailey v. Richardson, I82 F.2d 46 (1950); Stringer v. United States, 90 F. Supp. 375 (I950).

${ }^{2}$ Greene v. McElroy, 360 U.S. 474 (1959).

${ }^{3}$ Hearings on Procedures for Removal, Retirement, and Disciplining of Unfit Federal Judges Before the Subcomm. on Improvements in Judicial Machinery of the Senate Comm. on the Judiciary, 89th Cong., $2 \mathrm{~d}$ Sess. I (1966) [hereinafter cited as 2966 Hearings].

4 id. 
who drafted the federal Constitution rejected all proposals which would have subordinated judges to the administrative control of other judges, or even the legislative and executive branches of the government. In their desire to assure complete independence of the federal judiciary, they erected pervasive constitutional safeguards against the legislative control of judges.

Senator Sam J. Ervin, Jr., of North Carolina, a respected commentator on constitutional questions who formerly served as a justice of the supreme court of his state and who is a member of the Tydings subcommittee, has recognized the difficulties inherent in the existing scheme for control of judicial behavior:

Is there presently an alternative to impeachment for the removal of Federal judges? Should there be an alternative, especially in cases of physical or mental incapacity? ... [T] he answer to the first question is emphatically "no"... This brings us to the second question-the one crucial to us as a legislative and investigative subcommittee: should we provide an alternative, statutory if constitutionally permissible or by amendment if necessary, to article II, section 4 ? On the one hand we have the threat to judicial independence. But, on the other hand, it is neither intelligent, compassionate, nor, possibly, even legal, to subject an ill judge to impeachment by the House and trial by the Senate. It is, therefore, important to reach for a reasonable alternative. ${ }^{5}$

Senator Ervin's comments form the fundamental policy question presently occupying the attention of Congress and the Supreme Court of the United States. In a recent decision in Chandler v. Judicial Council of the Tenth Circuit, Chief Justice Burger struggled with the problem of legislative control of judicial behavior and what he called "the line defining the maximum permissible intervention consistent with the constitutional requirement of judicial independence." 8 Unfortunately, the Supreme Court stepped away from the statutory and constitutional vipers' nest involved in that case-whether a judicial council established by act of Congress ${ }^{7}$ had the power to strip a federal judge of the powers of his office to the extent of ordering him to hear no cases-on grounds that the case was not ripe for review.

Thus, the question of legislative control of judicial behavior remains open and subject to further debate. Can Congress legislate a civilian review board, an administrative agency, or a commission of other judges to determine the "good

\footnotetext{
Id. at 5 .

- Chandler v. Judicial Council, 398 U.S. 74, 84 (x970).

${ }^{7} 28$ U.S.C. $\$ 332$ states:

"The chief judge of each circuit shall call, at least twice in each year . . . a council of the circuit judges for the circuit, in regular active service, at which he shall preside. Each circuit judge, unless excused by the chief judge, shall attend all sessions of the council.

"The council shall be known as the Judicial Council of the circuit.

"The chief judge shall submit to the council the quarterly reports of the Director of the Administrative Office of the United States Courts. The Council shall take such action thereon as may be necessary.

"Each judicial council shall make all necessary orders for the effective and expeditious administration of the business of the courts within its circuit. The district judges shall promptly carry into effect all orders of the judicial council."
} 
behavior" of a sitting federal judge? Congressman Emanuel Celler, now Chairman of the House Judiciary Committee, said in 1940 that "good behavior is not a. justiciable question." House Resolution 9i60 which provided for removal of judges, other than those of the Supreme Court, upon trial by circuit judges designated by the Chief Justice of the Supreme Court. ${ }^{9}$ The bill was defeated in the House by a vote of 236 to ro4. This proposal, and others like it before and since, collide with the provisions of the federal Constitution intended by the founding fathers to place the federal judiciary in a position of independence beyond the reach of either of the other two coordinate branches of the federal government.

\section{II}

\section{Constitutional Provisions}

The provisions of the Constitution are explicit. Article III, section I provides that " $[t]$ he Judges, both of the supreme and inferior Courts, shall hold their offices during good Behaviour...." The limits of the phrase "during good Behaviour" are not further elaborated in the Constitution, and have not been outlined with any particularity in judicial decisions or impeachment proceedings. The Constitution includes only one procedure for the removal of a judge holding office during good behavior-the impeachment process. Article II, section 4 provides: "... all civil Officers of the United States, shall be removed from Office on Impeachment for, and Conviction of, Treason, Bribery, or other high Crimes and Misdemeanors." This includes judges.

\section{III}

\section{Constitutional Possibiutites}

Because article II, section 4 applies to federal civil officers other than judges, and there are a number of judicial decisions holding that impeachment is not the sole method of removing these other civil officers, ${ }^{10}$ an argument is made that Congress can also legislate the removal of judges by means other than impeachment. However, this argument overlooks the fact the Constitution gives federal judges a special status-a mandatory "shall" emphasizes their grant of good behavior tenure. ${ }^{11}$ This differentiates federal judges from other civil officers. ${ }^{12}$

\footnotetext{
${ }^{8}$ Quoted in H.R. Report on INvestigation of Judictal Behavion in the Tenth Circuit UNited States Court of Appeals BY the CoMmitee on the Judiciary, 90th Cong., 2d Sess. 73 (I968) [hereinafter cited as I968 RepoRT] (House Committee Print never acted on by full Committee).

${ }^{\circ}$ H.R. Rep. No. 537, 76th Cong., 3d Sess. (1940).

${ }^{10}$ See, e.g., Humphrey's Executor v. United States, 295 U.S. 602 (1935); Myers v. United States, I67 U.S. 324 (I897); Morgan v. TVA, II5 F.2d 990 (6th Cir. I940), cert. denied, 312 U.S. 70I (194x).

${ }_{11}$ U.S. CoNsT. art. III, $\$$ I.

${ }^{12}$ See Otis, A Proposed Tribunal; Is It Constitutional? 7 U. KaN. CrTY L. Rev. 3 (1938). Cf. Hearings on The Judicial Reform Act and Related Bills Before the Subcomm. on Improvements in
} 
Although no language in the Constitution explicitly proclaims that impeachment is the exclusive device by which to remove an allegedly unfit federal judge, the document implicitly eliminates any other conclusion. Article $I$, section 2 provides that "[t]he House of Representatives . . . shall have the sole Power of Impeachment," and section 3 provides that "[ $\mathrm{t}]$ he Senate shall have the sole Power to try all Impeachments."13 The familiar principle of legal construction, expressio unios est exclusio alterius, suggests that the Constitution establishes good behavior as a condition of federal judicial tenure, and impeachment as the exclusive device for its enforcement. ${ }^{14}$

Moreover, it seems fair to conclude that the term "sole" in its constitutional context defines two areas of exclusive relationships. The first defines a separation of powers within the Congress itself. To impeach is to charge a dereliction of duty, that is, a lack of good behavior or one of the enumerated constitutional derelictions of treason, bribery, or other high crimes and misdemeanors. It might be likened to a preliminary finding of probable cause. It is a very serious matter to charge a federal judge with misbehavior. Judges have a most delicate duty in the checks and balances of governmental functions and in the relationships among citizens. The judge is the arbiter and decisional authority in those personal controversies between citizen and citizen, or government and citizen, where efforts at compromise have failed. Backed by the authority of the state, the judge is the safety-valve intended to achieve justice acceptable to all parties so that there is no resort to violence. It is a natural consequence of the job that the losing parties frequently suspect the judge who rules against them is insane, lazy, dishonest, or otherwise lacking in good behavior and should be impeached. To provide insulation from the manifestations of this aspect of human nature, the founding fathers chose to place the power to charge judicial wrongdoing exclusively in the people's branch of Congress. Thus, the House of Representatives has the "sole" power of impeachment-the "sole" power to charge a lack of good behavior.

The second exclusive relationship defined by the Constitution, the Senate's "sole"

Judicial Machinery of the Senate Comm. on the Judiciary, 91st Cong., Ist Sess. 222 (1969) [hereinafter cited as 1969 Hearings] (memorandum on the constitutionality of a statutory alternative to impeachment); 'Judicial Fitness,' Hearings Before the Subcomm. on Improvements in Judicial Machinery of the Senate Comm. on the Judiciary, 8gth Cong., 2d Sess. (1966).

${ }^{13}$ Article I, section 2 states: "The House of Representatives shall chuse their Speaker and other Officers; and shall have the sole Power of Impeachment."

Article I, section 3 states:

"The Senate shall have the sole Power to try all Impeachments. When sitting for that Purpose, they shall be on Oath or Affirmation. When the President of the United States is tried, the Chief Justice shall preside: And no Person shall be convicted without the Concurrence of two thirds of the Members present.

"Judgement in Cases of Impeachment shall not extend further than to removal from Office, and disqualification to hold and enjoy any Office of honor, Trust or Profit under the United States: but the Party convicted shall nevertheless be liable and subject to Indictment, Trial, Judgment and Punishment, according to Law."

${ }^{14}$ See Hearings on H.R. I46 by the Subcomm. of the Senate Comm. on the Judiciary, 77th Cong., Ist Sess. 7 (I94I) (minority report). 
power to try impeachment cases, excludes from the removal process all other branches of the government. Article II, section 4 prescribes that civil officers, which include judges, "shall be removed from Office on Impeachment for, and Conviction of, Treason, Bribery, or other high Crimes and Misdemeanors."

Proponents of legislative control over judicial behavior argue that there is a "gap" between the kind of conduct for which impeachment will lie and the kind of conduct that would seem to be less than good behavior. ${ }^{15}$ Their argument proceeds on the theory that the framers were aware of the broad scope of impeachment in England, and limited the grounds for removal by Congress to relatively serious offenses similar in magnitude to treason and bribery. The phrase "high Crimes and Misdemeanors" to them does not include such types of judicial unfitness as incompetence, laziness, insanity, senility, alcoholism, and corruption.

Legislative control of the behavior of federal judges has found its most recent expression in the Ninety-first Congress in Senate Bill 1506, providing for a Commission on Judicial Disabilities and Tenure with power to "undertake an investigation of the official conduct of any judge of the United States appointed to hold office under Article III of the Constitution to determine whether the conduct of such judge is and has been consistent with the good behavior required by that article." The Commission would be composed of five federal judges in active service and would have the power to recommend to the Judicial Conference that the judge be removed for "willful misconduct in office or willful and persistent failure to perform his official duties" on grounds that this would "constitute conduct inconsistent with the good behavior required by Article III of the Constitution and shall be cause for the removal of that judge." This proposal is based on the "gap" theory.

Proponents of the legislation have said,

Impeachment is perhaps the sole method of removal of Federal judges that may be constitutionally employed by the Congress, for the principle of an independent judiciary free from interference by the legislative or executive branches, is central to the concept of a government of separated powers. But this is not to say that impeachment is the only constitutionally permissible method of removing a Federal judge from office. It should be borne in mind that a judge is to serve "during good behaviour," while impeachment lies only for bribery, treason, "high Crimes and Misdemeanors." It may be that the framers of the Constitution intended to permit other methods of removal not inconsistent with the separated powers. The scholarship on this point is disappointingly sparse, and I hope that one of the effects of our study will be to stimulate some scholarly reexamination of the arguments for and against the exclusivity of impeachment as a removal process from the Federal bench. ${ }^{18}$

In testifying on Senate Bill I506, the Department of Justice urged strongly that impeachment is not the only constitutionally permissible method for removal of

${ }^{18}$ rg69 Hearings, stpra note 12.

${ }^{16}$ Id. at 4. 
judges and that compulsory retirement complies with the Constitutional provision for tenure during good behavior. According to their view, tenure during good behavior has its roots in the England of the Middle Ages. Historically, it constituted a grant of office for life terminable upon breach of the condition that the incumbent behave himself well. The condition was breached by misfeasance in office or failure to perform the duties of the office. The question whether the condition was violated and the office forfeited was determined in a judicial proceeding in the nature of scire facias. Since English judges who served at the pleasure of the King until judicial good behavior tenure became law in the Act of Settlement of I7or were similarly removable, the Justice Department takes the view that nothing on the face of the constitutional provisions written in 1789 makes impeachment the exclusive method for the removal of judges. ${ }^{17}$

The various opinions and dissents of the Justices of the Supreme Court in the Chandler case shed a good deal of light on the problem of legislative control of judicial behavior as distinguished from legislative control over the administrative details of operation of the federal courts. This case, for the first time, raised the question of whether Congress can exercise control over the conduct of federal judges without specifically charging a lack of good behavior. In that case Judge Stephen S. Chandler, a federal district judge for the Tenth Circuit, petitioned the Supreme Court for a writ of mandamus or alternatively a writ of prohibition addressed to the Judicial Council of the Tenth Circuit. That judicial council, composed of five judges of the Court of Appeals, entered an order in 1965 prohibiting Judge Chandler from taking any "action whatsoever in any case or proceeding now or hereafter pending in the U.S. District Court for the Western District of Oklahoma" on grounds he was "unable or unwilling to discharge efficiently the duties of his office."

Congress, which created the lower federal courts in $x 789$, undertook in $x 939$ to create a judicial council for each circuit composed of the judges for the circuit in active service. The councils are empowered to make all necessary orders for the administration of the business of the courts within each circuit. The same law also established an administrative office of the United States courts to compile statistical data, and a Judicial Conference, composed of circuit and district judges and members of the bar. ${ }^{18}$ Judge Chandler refused to recognize the Council's order on the ground it had usurped the impeachment power committed by the Constitution exclusively to Congress.

The dissent of Justice Douglas stated the case against legislative control of good behavior thusly:

\footnotetext{
${ }^{17}$ See Pergles, Trial of Good Behavior of Federal Jesdges, 29 VA. L. Rev. 876-77 (I943); Note, Removal of Federal Judges: A Proposed Plan, 3 I ILL. L. Rev. 63r, 639 (1937).

${ }^{18} 28$ U.S.C. $\$ \$ 332,333,601,604(1964)$; See also, H.R. Rep. No. 702, 76th Cong., Ist Sess. 2 (1939).
} 
An independent judiciary is one of this Nation's outstanding characteristics. Once a federal judge is confirmed by the Senate and takes his oath, he is independent of every other judge. He commonly works with other federal judges who are likewise sovereign. But neither one alone nor any members banded together can act as a censor and place sanctions on him. Under the Constitution the only leverage that can be asserted against him is impeachment, where pursuant to a resolution passed by the House, he is tried by the Senate sitting as a jury ....

What the Judicial Council did when it ordered petitioner [Judge Chandler] to "take no action whatsoever in any case ..." in his court was to do what only the Court of Impeachment can do. If the business of the federal courts needs administrative oversight, the flow of cases can be regulated. . . . Matters of this kind may be regulated by the assignment procedure. But there is no power under our Constitution for one group of federal judges to censor or discipline any federal judge and no power to declare him inefficient and strip him of his power to act as a judge. ...

It is time that an end be put to these efforts of federal judges to ride herd on other federal judges. This is a form of "hazing" having no place under our Constitution. Federal judges are entitled, like other people, to the full freedom of the First Amendment. If they break a law, they can be prosecuted. If they become corrupt or sit in cases in which they have a personal or family stake, they can be impeached by Congress. ... Only Congress can take action, unless the Constitution is amended to allow judges to censor, police, or impeach their fellow judges. ${ }^{19}$

Later on we will see that Justice Black dissented with similar views and both he and Justice Douglas each joined in the other's dissent. As also indicated below, Chief Justice Burger recognized that, "Whether the action taken by the Council with respect to the division of business in Judge Chandler's district falls to one side or the other of the line defining the maximum permissible intervention consistent with the Constitutional requirement is the ultimate question."20

The most workable solution to the existing dilemma would seem to be a recognition that, like other terms and phrases in the Constitution, good behavior is broad enough to include all acts or omissions by a federal judge which would interfere with his capacity to do his job. To ensure that the federal judiciary not be burdened with either the dishonest or the incompetent, impeachable conduct must necessarily include any such lack of good behavior, whether prescribed by an existing statute or not. Judicial independence requires a certain strictness in confining impeachable lack of good behavior, apart from treason, bribery, high crimes and misdemeanors, to situations where a judge, because of physical or mental disability, senility, corruption, alcoholism, incompetence, laziness, or misfeasance simply fails to perform his duties. There is far less danger to judicial independence from this approach than from either amending the Constitution to broaden the

\footnotetext{
${ }^{19}$ Chandler v. Judicial Council, 398 U.S. 74, $136-37,140-4 \mathrm{r}$ (1970).

${ }^{20} 398$ U.S. at 84.
} 
grounds for impeachment or construing the present provisions as leaving a "gap" that Congress can fill by legislating control over judicial behavior. The present impeachment procedure is sufficiently formal and cumbersome to protect judicial independence while at the same time providing a mechanism reasonably structured to remove a truly unfit federal judge. Judicial independence and a broader use by Congress of the existing impeachment machinery to deal with unfit judges are not inconsistent.

It can reasonably be concluded that the phrase "high Crimes and Misdemeanors" comprehends not only legal wrongdoing, such as dishonesty, drunkenness, and personal misconduct, but such non-legal misdemeanors as incompetence, laziness, and failure to perform the duties of the office of judge, whether due to senility, insanity, illness, or any other reason. In Story's Commentaries on the Constitution, there are recounted occasions when English judges were impeached for acting contrary to the duties of office and rendering unconstitutional opinions. ${ }^{21}$

Further, evidence is persuasive that the framers themselves intended good behavior to have a broad meaning. In No. $6_{5}$ of The Federalist Papers, Alexander Hamilton suggested that the Constitution does not permit a determination on the issue of fitness or good behavior of a judge by any forum but the Senate. In the words of Hamilton:

The remaining powers which the plan of the Constitution allot to the Senate, in a distinct capacity, are comprised in their participation with the executive in the appointment to offices, and in their judicial character as a court for the trial of impeachments. ${ }^{22}$

In No. 39 of The Federalist Papers, James Madison stated, "The tenure by which the judges are to hold their places is, as it unquestionably ought to be, that of good behavior."23 Hamilton in his description of the functions of the Senate as a judicial court for the trial of impeachments in Federalist No. 65 goes on to say that

A well-constituted court for the trial of impeachments is an object not more to be desired than difficult to be obtained in a government wholly elective. The subjects of its jurisdiction are those offenses which proceed from the misconduct of public men, or, in other words, from the abuse or violation of some public trust. ${ }^{24}$

Hamilton devotes Nos. 65 and 66 to a long discussion of the impeachment process, the need for a tribunal in which the people will have confidence, and the delicacy and magnitude of prosecuting and judging charges against political figures

\footnotetext{
${ }^{21}$ II J. Stort, Commentaries on the Constitution 1800 (4th ed. I873). See also 1969 Hearings, stepra note I2.

${ }_{22}^{2}$ The Federalist No. 65, at 396 (New American Library of World Literature ed. I96r) (Hamilton).

28 Id. No. 39, at 242 .

24. Nd. No. 65 , at 396 .
} 
appointed by the President. He adverts to article I, section 3, clause 7, which limits the power of the Senate in exercising its judicial authority as a court of impeachment: "Judgment in cases of impeachment shall not extend further than removal from office, and disqualification to hold and enjoy any office of honor, trust, or profit, under the United States; but the party convicted shall, nevertheless, be liable and subject to indictments, trial judgments, and punishments according to law."

The fact that the Constitution contains no enumeration of offenses comprised under "high Crimes and Misdemeanors" has led to some difficulties in construction. Some meaning of the phrase can be gleaned from Hamilton's interrogatory in The Federalist No. 65, when, discussing rejection of the Supreme Court by the Convention as an improper tribunal for impeachments, he asks whether the impeachment procedure was not "designed as a method of NATIONAL INQUEST into the conduct of public men?"25

Some historians contend that the words "high Crimes and Misdemeanors" derive from the impeachment in 1787 , during the time the Constitutional Convention was in session, by the House of Commons of Warren Hastings, first Governor General of Bengal for "high crimes and misdemeanors." The charges against Hastings were confiscation of property and oppressiveness in government, which permits inference of the English definition of the term at the time. ${ }^{2 B}$ However, other scholars insist that impeachable offenses were not defined in England and it was not the intention that the Constitution should attempt an enumeration of crimes or offenses for which an impeachment would lie. The Legislative Reference Service of the Library of Congress has said:

Treason and bribery have always been offenses whose nature was clearly understood. Other high crimes and misdemeanors which might be made causes for the impeachment of civil officers were those which embraced any misbehavior while in office. $^{27}$

Madison, whose objection led to the insertion of the more definite phrase "high Crimes and Misdemeanors," was the strongest advocate of a broad construction of the impeachment power. He argued that "incapacity, negligence, or perfidy" should be grounds for impeachment. ${ }^{28}$ Hamilton thought an impeachment proceeding could "never be tied down by such strict rules, either in the delineation of the offense by the prosecutors, or in the construction of it by the judges, as in common cases serve to limit the discretion of the courts in favor of personal security."20 In

\footnotetext{
${ }^{25}$ Id. at 397 .

${ }^{26}$ T. Norton, The Constitution of the United States, Its Sources and Its Application 229 (Committee for Constitutional Government ed. I943).

${ }^{27}$ Legislative Reference Service, Library of Congress, The Constitution of the United States $55^{6}$ (N. Small ed. I964).

${ }^{28} 5$ J. Elliott, Debates $34 \mathrm{x}, 447$ (1937).

20 The Federaisst, supra note 22, No. 65, at 398. See also W. Carpenter, Judicial Tenure in the UNITED STATES 105 (19I8).
} 
discussing the Senate's "judical character as a court for the trial of impeachments," he described impeachable offenses as including those "of a nature which may with peculiar propriety be denominated POLITICAL, as they relate chiefly to injuries done immediately to society itself."30

\section{IV}

\section{Historjcal Perspective}

The growing swell of criticism ${ }^{31}$ in recent years that existing procedures for removal or retirement of unfit federal judges are inadequate and ineffective tends to remain blind to the commentary in the Federalist Papers, the debates of the Constitutional Convention contained in the papers of James Madison, ${ }^{32}$ and the history of the Constitution itself.

The Colonial Declaration of Rights of October 14, I774, complained that judges were "dependent on the Crown alone for their salaries." A similar complaint in the Declaration of Independence was that King George III "has made judges dependent on his will alone for the tenure of their office and the amount and payment of their salaries."

Lecky mentions in England in the Eighteenth Century, that there was "a long and bitter quarrel about the position of the judges" in the Colonies. He says that the colonists wished the judges to hold their office during good behavior and thus be beyond the control of the home government. The King of England, becoming dissatisfied with the conduct of the colonists, demanded the surrender of their charters. This being resisted, a proceeding in quo warranto (inquiring by what warrant they claimed rights) was instituted in the courts of England and, as Story well said, "it terminated, as in that age it might well be supposed it would, in a judgment pronounced in 1624 by judges holding their office during his pleasure that the franchises were forfeited ....".33

In the debates at the federal Constitutional Convention of 1787 as reported in The Papers of James Madison, Edmund Randolph read before the Convention a resolution "that a National Judiciary be established ... to hold their office during good behavior . ..."34 John Dickinson moved that after the words "good behavior," the words "provided that they may be removed by the Executive on the Application by the Senate and House of Representatives" be added. ${ }^{35}$ Mr. Gouveneur Morris thought it a contradiction in terms to say that the judges should hold their offices during good behavior, and yet be removable without a trial, and in any

\footnotetext{
${ }^{30}$ THE Federalist, $i d$. at 396.

${ }^{31}$ See, e.g., II6 Cong. REC. S5372-74 (daily ed. April 8, 1970); 1966 Hearings, supra note 3; 1969 Hearings, supra note 12.

${ }^{82} \mathrm{~J}$. Madison, The Papers of James Madison (H. Gilpin ed. 1840).

${ }^{38}$ II STORY, supra note 2I, I 46 .

${ }^{86} \mathrm{~J}$. MAdison, stipra note 32, at 743.

${ }^{B 5}$ Id. at 1436 .
} 
event, it was wrong to subject judges to so arbitrary an authority. ${ }^{30}$ Roger Sherman of Connecticut "observed that a like provision was contained in the British statutes."37 But James Wilson of Pennsylvania argued "The judges would be in a bad situation if made to depend on any gust of faction."38 Mr. Randolph "opposed the motion as weakening too much the independence of the judges."30 The debates also show that at one point the Convention considered extending the jurisdiction of the Supreme Court to "cases of impeachment" but this approach was explicitly negatived on grounds that judges should not be subjected to an ordinary judicial trial..$^{40}$

Those who espouse a constitutional basis for legislative control over the behavior of judges by some body other than the Senate sitting as a court of impeachment ignore the exhaustive analysis of this question by Alexander Hamilton in The Federalist No. $6_{5}$ and the rejection of the Supreme Court as an alternative forum:

The convention, it appears, thought the Senate the most fit depository of this important trust. ... The necessity of a numerous court for the trial of impeachments is equally dictated by the nature of the proceeding. ... The awful discretion which a court of impeachments must necessarily have to doom to honor or infamy the most confidential and the most distinguished characters of the community forbids the commitment of the trust to a small number of persons. These considerations seem alone sufficient to authorize a conclusion that the Supreme Court would have been an improper substitute for the Senate .... ${ }^{41}$

Most of the constitutions of other nations which have been drafted since ours have adopted the provision making the term of judges during good behavior, and many of them prohibit the intimidation of the judge by the reduction of his salary. ${ }^{42}$ By the constitutions of Belgium (1831-1873) and Brazil (r890) judges are appointed for life. In Argentina (1853, 1860 ) and Chile (1833-1893) the judges hold office during good behavior. It is significant that the constitutions of the three great British dependencies, those of the Dominion of Canada (1867), the Commonwealth of Australia (Ig00), and the Union of South Africa (Ig09), follow explicitly that of the United States in requiring that judges be appointed, that they hold office during good behavior, and that their salaries not be reduced. Canada has seen the practical operation of this clause of our Constitution for over a century. It was more than a century and a decade old when Australia followed it. In Igog, when the Union of South Africa was established, this constitutional provision had served for I20 years the great purpose for which it was designed. ${ }^{43}$

In Federalist Paper No. 39, written by James Madison, the whole structure of

${ }^{88} I d$.

st Id.

${ }^{88} \mathrm{Id}$.

${ }^{80} I d$.

${ }^{10} \mathrm{Id}$. at I 438 .

11 The Federaisst, supra note 22, No. 65, at 398.

12 T. Norton, supra note 26, at I34; Ir6 Conc. Rec. Ex749 (daily ed. Mar. 9, 1970) (statement of Congressman Fletcher Thompson of Georgia).

${ }^{43}$ T. Norton, supra note 26 , at 134 . 
terms of offices of members of the House of Representatives, members of the Senate, and the President is discussed, in terms of providing a republican form of government, and Madison says, "The tenure by which the judges are to hold their places is, as it unquestionably ought to be, that of good behavior." ${ }^{\text {"44 }}$ Again in No. 5r, in discussing the structure of government provided in the federal Constitution as being one of three separate but coordinate branches of government, Mr. Madison said,

To what expedient, then shall we finally resort, for maintaining in practice the necessary partition of power among the several departments as laid down in the Constitution? The only answer that can be given is that as all these exterior provisions are found to be inadequate the defect must be supplied by so contriving the interior structure of the government as that its several constituent parts may, by their mutual relations, be the means of keeping each other in their proper places. ... In the constitution of the judiciary department, ... the permanent tenure by which the appointments are held ... must soon destroy all sense of dependence on the authority conferring them. ${ }^{45}$

In Federalist Paper No. 78, Alexander Hamilton discusses the defects existing under the Articles of Confederation necessitating a federal judiciary. He says:

According to the plan of the convention, all judges who may be appointed by the United States are to hold their offices during good behavior. . . . The standard of good behavior for the continuance in office of the judicial magistracy is certainly one of the most valuable of the modern improvements in the practice of government. In a monarchy it is an excellent barrier to the despotism of the prince; in a republic it is a no less excellent barrier to the encroachments and oppressions of the representative body. And it is the best expedient which can be devised in any government to secure a steady, upright, and impartial administration of the laws. . . .

The complete independence of the courts of justice is peculiarly essential in a limited Constitution. ...

If, then the courts of justice are to be considered as the bulwarks of a limited Constitution against legislative encroachments, this consideration will afford a strong argument for the permanent tenure of judicial offices, since nothing will contribute so much as this to that independent spirit in the judges which must be essential to the faithful performance of so arduous a duty.

This independence of the judges is equally requisite to guard the Constitution and the rights of individuals from the effect of those ill humors which the arts of designing men ... sometimes disseminate among the people . . . and which ... occasion dangerous innovations in government. ...

-...

That inflexible and uniform adherence to the rights of the Constitution, and of individuals, which we perceive to be indispensable in the courts of justice, can certainly not be expected from judges who hold their offices by a temporary com-

4t THE Federalist, supra note 22, No. 39, at 242.

LE Id. No. 5I, at 320-2I. 
mission. Periodical appointments, however regulated, or by whomsocver made, would, in some way or other, be fatal to their necessary independence. ${ }^{46}$

The original flexible conception of "high Crimes and Misdemeanors" was for a time given more of a restricted meaning as a result of Thomas Jefferson's efforts to diminish the importance of the Supreme Court, the first step of which was the impeachment in I804 of Justice Samuel Chase. Senator Giles of Virginia, a staunch supporter of Jefferson and a political enemy of Justice Chase, stated the case thusly:

Impeachment is nothing more than an inquiry, by the two Houses of Congress, whether the office of any public man might not be better filled by another. ... The power of impeachment was given without limitation to the House of Representatives; and the power of trying impeachments was given equally without limitation to the Senate; ..... A trial and removal of a judge upon impeachment need not imply any criminality or corruption in him. . . . [It is] nothing more than a declaration of Congress to this effect: You hold dangerous opinions, and if you are suffered to carry them into effect you will work the destruction of the nation. We want your offices, for the purpose of giving them to men who will fill them better. ${ }^{47}$

Justice Chase's counsel based his defense on the notion that "high Crimes and Misdemeanors" meant only offenses indictable at common law. ${ }^{48}$ Since Chase was acquitted, it could be argued that the Senate accepted this defense, but it seems just as likely that the Senate simply did not consider Chase's activities as evidencing lack of good behavior sufficient to justify removal. Some scholars contend that Chase's acquittal suggests the House misconstrued its authority in impeaching. But it is as logical to contend he was acquitted by the Senate for failure of proof, or a failure to state a cause of action, or some other ground, and that his acquittal is evidence of the soundness of impeachment as the sole procedure for determining good behavior. The important fact is that "high Crimes and Misdemeanors" was considered at the very beginning to be comprehensive enough for the House to impeach a Supreme Court Justice on grounds of replacing the Justice with a man who would fill the office "better."

The history of impeachment of federal judges by the House sustains the view that "high Crimes and Misdemeanors" contemplates all kinds of misbehavior, and that there is no so-called gap between the kinds of conduct for which impeachment will lie and the kind of conduct that would seem to be less than good behavior. ${ }^{50}$ In 1803 , federal judge John Pickering was impeached, and removed from office, for misconduct in a trial and for being on the bench while intoxicated. ${ }^{61}$ In 1804 , Supreme Court Justice Samuel Chase was impeached for misconduct and impairing

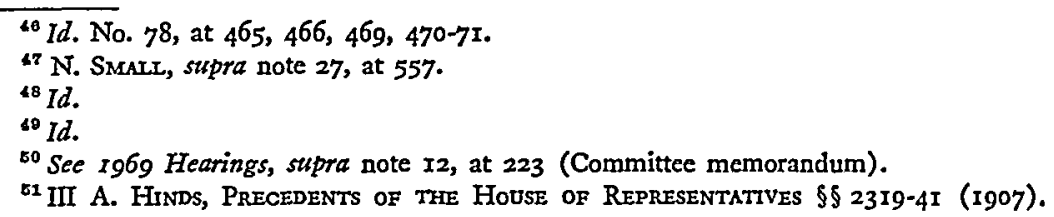


the confidence and respect for the courts, and acquitted, as outlined above. ${ }^{52}$ In 1826, federal district judge James $H$. Peck was impeached for misuse of the contempt power and acquitted. ${ }^{53}$ In 1862 , federal district judge West $\mathrm{H}$. Humphreys was impeached for supporting the secession of Tennessee and acting as a judge of a district court of the Confederate States of America. He was removed from office and disqualified to hold any office of trust, honor, or profit under the United States. ${ }^{54}$ In I903, federal district judge Charles Swayne was impeached for padding expense accounts, using railroad property in receivership for his personal benefit, and misusing his contempt power. He was acquitted.55 While most of these earlier impeachments were for criminal lack of good behavior, a procedure that can deal with such matters as intoxication and expense account padding can certainly deal with such derelictions of duty as laziness or unfitness. It can also deal with disability, whether the disability is senility, illness, or incompetence.

In 1912, federal Commerce Court judge Robert W. Archbold was impeached for misconduct which included accepting personal profits and free trips to Europe and improper appointment of a jury commissioner. He was removed from office and disqualified thereafter from holding any federal office. ${ }^{56}$ In 1926 , federal district judge George W. English was impeached for gross abuse of power, profane and abusive conduct in the courtroom, collusion, partiality, and favoritism in bankruptcy proceedings. The court proceedings in the Senate were adjourned on December I3, 1926, after Judge English resigned on November 4, x926.57 In 1932, federal district judge Harold Louderback was impeached for appointing incompetent receivers and allowing them excessive fees, ${ }^{58}$ but he was acquitted. In 1936, federal district judge Halsted L. Ritter was impeached for participating in champertous proceedings brought before him for a cash consideration, practicing law while serving as a federal judge, and preparing and filing false income tax returns. ${ }^{50} \mathrm{He}$ was removed from office. These later impeachments included multitudinous charges relating to noncriminal unfitness or lack of good behavior.

The Constitution specifically limits the Senate's action to removal from office and, in appropriate cases, a bar to future office. The punishment for criminal acts is left to other forums. This rather flexible power to protect the judicial function, by a two-thirds decision of the Senate, by removal from office and possibly, in addition, a bar to future office, is peculiarly suited to maintaining maximum judicial independence. Certainly Congress has found itself able to move against federal judges for "free-loading" trips to Europe and profane and abusive conduct in court as

\footnotetext{
${ }^{52}$ III $i d$. at $\$ \S 2342-63$.

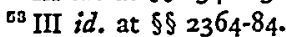

ou III $i d$. at $\$ \$ 2385-97$.

sE III id. at $\$ \$ 2469-85$.

${ }^{8}$ VI C. Cannon, Precedents of the House of Representatives $\$ \$ 498-512$ (1935).

${ }^{E 7} \mathrm{VI}$ id. at $\$ \$ 544-47$.

${ }^{\mathrm{CB}} \mathrm{VI} i d$. at $\$ \$ 513-24$.

5o 80 Cong. Rec. 497I (I936).
} 
well as standing in the way of a "better" man, tax fraud, collusion, and partiality. Why cannot Congress, under existing constitutional provisions, deal with federal judges who are senile, alcoholic, incompetent, or just plain lazy? The record shows that in well-founded cases, federal judges resign rather than risk removal from office. It also shows acquittal when impeachment charges are not well founded. This would seem to be a proper structure to maintain an independent but efficient federal judiciary system. Any legislative tinkering in terms of good behavior may disturb the balance.

\section{Historical Conclusions and Contemporary Lessons}

The history of the impeachment process indicates that only eight federal judges have ever been impeached, and of these four were convicted. As may be seen from the above summary, there have been cases involving drunkenness, dishonesty, abusive behavior, abuse of power, income tax fraud, corruption, and other types of misconduct. It should be noted that the convictions occurred in cases where there was distinct unfitness based on moral turpitude, while the acquittals involved cases in which the "unfitness" appeared to have been based more on political considerations. This reflects the manner in which checks and balances are to work within the system. The impeachment procedure is deliberately a cumbersome, refining, and involved process, so that judicial fear of casual impeachment and removal from office will be minimized and a judge's freedom to decide cases on the merits can be maximized.

This deliberate impeachment procedure itself forces the voluntary retirement of most senile, alcoholic, corrupt, or otherwise unfit judges to avoid the disgrace of public censure, when there are adequate grounds. The official conduct of fifty-six federal judges has been the subject of inquiry by Congress. Eight were impeached, eight censured but not impeached, seventeen resigned at one stage or another in the conduct of the investigation, and the rest were absolved of impeachable conduct. ${ }^{00}$

The present controversy over the proposed impeachment of Supreme Court Justice Douglas illustrates the continuing argument over the type of misconduct which the impeachment process encompasses. House Minority Leader Gerald Ford has stated that good behavior consists of "whatever a majority of the House of Representatives considers [it] to be at a given moment in history," Douglas' relationships with "pornographic" magazines, a taz-free foundation financed by gambling proceeds, and his book, Points of Rebellion, constituted an impeachable offense. Such a view is in keeping with the historical precedents set out above that good behavior must necessarily include all types of "off-the-bench" activities which conflict with public confidence in the judicial system. It further

\footnotetext{
${ }^{60} 1969$ Hearings, supra note $x_{2}$, at 104 (testimony of Joseph Borkin, author of The Corrupt Judge).

${ }^{01}$ I 6 CoNG. REc. H3II2 (daily ed. Apr. I5, I970) (statement of Congressman Gerald Ford).
} 
recognizes that the Constitutional impeachment procedures are adequate to meet any situation involving good behavior.

The House Judiciary Committee has described how well the present system works to balance judicial independence with a reasonable control over removal of unfit judges for a lack of good behavior:

The procedure that applies to impeachments, although rarely used, is characterized by a high degree of formality. The Judiciary Committee makes a preliminary informal examination of charges brought against judges. If, in the opinion of the Committee, an impeachment is warranted, specific authority and direction is sought by resolution from the House to conduct an investigation of the particular charges involved. Adoption of the resolution is followed by an exhaustive examination into the charges. Impeachment may be initiated by a Member on his own responsibility; by a memorial containing charges under oath; by a message from the President; by a charge preferred by a State legislature; and by petition.

Hearings on a record are conducted, and the accused and the accusers are accorded the privilege to appear in person, to be represented by counsel, and to examine and cross examine witnesses. The accused may testify in his own behalf. After full considerations in executive session the Committee makes its report to the House, and if the judgment is for impeachment, articles of impeachment are presented to the House with the Committee report. The House debates and votes on the question of impeachment. If an impeachment is voted by a majority of the House, managers are appointed to conduct the trial in the Senate. The managers are agents of the House, and, in general, they are named from members of the Judiciary Committee. The managers present themselves at the bar of the Senate and demand the impeachment of the accused in the name of the House of Representatives and of all of the people of the United States.

The Senate furnishes the accused with a copy of the charges against him, and fixes the date for the trial to begin. The Senate organizes itself into a court of impeachment and the trial is held in the Senate Chamber. The Vice President presides, unless the President of the United States is on trial. In as much as the Vice President would have a personal interest in the outcome, the chair in such case is occupied by the Chief Justice of the United States.

The accused is allowed counsel, and may appear and give testimony in person; and witnesses for and against him are brought in and questioned. At the close of the proceedings, which may last through many weeks, the galleries are cleared and the Senate votes. A two-thirds vote is necessary to convict. In case of conviction, the penalty is removal from office, and disqualification to hold any office of honor, trust, or profit under the United States. The President's power of pardon and reprieve does not apply. An impeached person, however, is liable to indictment, trial, and punishment at law as any other offender. ${ }^{62}$

It is clear from the above that all of the machinery necessary for a full and fair investigation, complete with due process, is provided under the present constitutional structure to remove unfit judges. Those who insist that the present provisions of

\footnotetext{
${ }^{\circ 2}$ x968 REPORT, supra note 8, at 5.
} 
the Constitution are not adequate to do the job overlook the considerations shown by history to weigh so heavily on the side protecting judicial independence. The Constitution was written in contemplation of the stresses that would occur in peace, war, times of social change, and in periods of unrest. Thomas Jefferson wrote, "In questions of power, then, let no more be heard of confidence in man, but bind him down from mischief by the chains of the Constitution." No greater need for chains can be shown than that protecting judicial independence from easy legislative or executive control through removal. Supreme Court Justice Hugo Black in a recent dissent stated:

One of the great advances made in the structure of government by our Constitution was its provision for an independent judiciary-for judges who could do their duty as they saw it without having to account to superior court judges or to anyone else except the Senate sitting as a court of impeachment. ${ }^{03}$

\section{VI}

\section{Proposals FOR ReFoRM}

Proponents of legislation to provide some alternate method for removal of federal judges sometimes call on Lord Bryce's statement in The American Commonwealth that "Impeachment . . . is the heaviest piece of artillery in the congressional arsenal, but because it is so heavy it is unfit for ordinary use." ${ }^{" 64}$ Or they ignore Thomas Jefferson's early support of trial by the Senate to determine good behavior and stress his later politically inspired description of impeachment as a "bungling way of removing Judges . . . an impractical thing-a mere scarecrow"105 and his statement in a letter that "impeachment is a farce which will not be tried again."

These proponents persist in ignoring the stress the Constitution writers laid on judicial independence. In The Federalist No. 79, Hamilton said, "Next to permanency in office, nothing can contribute more to the independence of the judges than a fixed provision for their support. ... Together with the permanent tenure of their offices, it affords a better prospect for their independence . . .."07 Sometimes in judicial decisions the Supreme Court and other courts have recognized that good behavior means life or permanent tenure. ${ }^{68}$ The courts also recognize that life

\footnotetext{
${ }^{63}$ Chandler v. Judicial Council, 382 U.S. 1003, roo5 (1966) (dissent of Justice Black).

66 J. Bryce, The American Commonwealth 158 (MacMillan ed. 1908).

${ }^{05}$ As quoted in I C. Warren, The Supreme Court 295 (1926).

${ }^{\circ 6}$ Letter from Jefferson to Senator William Giles, April 20, 1807 , in 2 T. Jepferson, WritnNGs IIgr (I904).

${ }^{67}$ The Federalist, stipra note 22, No. 79, at 472, 474; See also Note, Removal of Federal judgesAlternatives to Impeachment, 20 VAND. L. REv. 723 (I967); Note, Judicial Trial and Removal of Federal Judges: H.R. 146, 20 TEXas L. REv. 352 (1942); Kramer and Barron, The Constitutionality of Removal and Mandatory Retirement Procedures for the Federal Judiciary: The Meaning of "Good Behavior," 35 Geo. WAsh. L. REV. 455 (1967); Shartel, Federal Judges-Appointment, Supervision and RemovalSome Possibilities Under the Constitution, 28 Mrch. L. Rev. 870 (1930); Note, Removal of Federal Judges: A Proposal Plan, 3I ILL. L. REv. 63I (1937).

${ }^{68}$ See, e.g., O'Donoghue v. United States, 289 U.S. 516, 549 (1933); Shurtleff v. United States, 189 U.S. 31I, 3I6 (1903).
} 
tenure is subject to good behavior. ${ }^{69}$ History and experience have given a balanced meaning to judicial independence and good behavior.

When all of the available literature and decisions are considered, there is an inexorable and inevitable conclusion that good behavior is, indeed, not justiciable in any forum except in impeachment proceedings in Congress. ${ }^{70}$ There would seem to be no logical basis for an assumption that the article III constitutional provision that judges are to serve during good behavior impliedly grants power to Congress to define or authorize some federal agency to prescribe behavior that is other than good. The history of the language, the comments of Hamilton and Madison, the rejection of all proposals to remove federal judges other than by impeachment indicate that articles I, II, and III are an absolute bar to any legislative or executive control over the good behavior tenure of judges. Stated another way, until a judge is impeached by the House and convicted by the Senate, article III raises a conclusive presumption that his performance of duty conforms to the good behavior condition of tenure established by the Constitution. ${ }^{11}$

In Federalist No. 78, Hamilton devotes lengthy explanation to the need of removing any possibility of the "executive or legislative" placing judges in a position where their independence might be influenced by an unwillingness to hazard the displeasure of either. ${ }^{72}$ In Federalist No. 79, Hamilton makes it clear beyond cavil or doubt that the impeachment procedures of article III are deliberately exclusive as to good behavior, and prohibit any legislative or executive procedure "for removing the judges on account of inability."73 The separation of powers principle must surely arise a constitutional bar to any form of legislative control over good behavior. $^{74}$ In the I8I years of our national existence there has not been one demonstrable case of ultimate injustice because of an unfit federal judge. All errors or derelictions have been corrected by review or intervention of other courts within their proper jurisdictional powers.

However, the subtle attack on the independence of the federal judiciary is renewed periodically, usually in terms of legislative control of good behavior. On April 7, I970, when Senator Sam J. Ervin, Jr., of North Carolina, Chairman of the Senate Subcommittee on Separation of Powers, commenced hearings on the Judicial Conference and the judicial councils of the circuits, he said,

\footnotetext{
${ }^{10}$ McAllister v. United States, I4I U.S. I74, Igo (I8gI). See also Myers v. United States, 272 U.S. 52 (1926); Humphrey's Executor v. United States, 295 U.S. 602 (1934); United States v. Fisher, I09 U.S. I 43 ( $\left.188_{3}\right)$.

${ }^{70}$ See H.R. Rep. No. 537, 76th Cong., 3d Sess. (1940); 81 Cong. Rec. 6157-58; 6161-62; 6163-65; $6 \mathrm{r} 60-73 ; 6 \mathrm{r} 87$ (r937).

${ }^{71}$ McAllister v. United States, I4I U.S. I74, I94 (189I). See also Ex Parte Bakelite Corp., 279 U.S. 438 (I928); Glidden v. Zdanok, 370 U.S. 530 ( 1962 ).

73 The Federalist, stpra note 22, No. 78, at 465-72.

${ }^{73} \mathrm{Id}$. No. 79, at 474 .

Tt See Otis, supra note 12; Brown, The Impeachment of the Federal Judiciary, 26 HARv. L. Rev. 330 (1937).
} 
No less than 27 bills are now before the House and Senate. . . For more than 200 years, a majority in the Congress has fought to maintain the independence of our judiciary-an independence that protects the public and the rule of law rather than the judges themselves. We have sought to guarantee that no outside influence can invade a judge's chambers or determine how he decides a case. These 27 bills, to one extent or another, would undermine that independence. Some of them, while well-intentioned, would introduce new extra-judicial influences into the Federal court system. It may be that the Congress is prepared to sacrifice judicial independence in order to impose guidelines on judicial behavior; but if that is the case, the issue should be stated in those terms, not in the glowing language of making improvements in the administration of the courts. ${ }^{75}$

Another look at the activities of Congress referred to above may shed more light. When Senator Tydings first became chairman of the subcommittee on October 15 , I965, he announced he would undertake an extensive study of the "problems caused by disabled judges and by judges whose conduct fails to meet the standards of good behavior required by the Constitution."76 When, on February 15, I966, Senator Tydings announced that he would investigate "the availability of and need for procedures to govern the removal, retirement, and disciplining of unfit Federal judges," ${ }^{77}$ he alluded to an existing situation involving interference with federal Judge Stephen S. Chandler by a judicial council as one cause for the hearing:

The Chandler case has brought to the attention of the Nation a situation that has troubled many observers-including Senators and Congressmen-for a long time.

For reasons that have not yet been made clear, the Judicial Council of the roth Judicial Circuit ... reached the conclusion that the chief judge of the western district of Oklahoma, Stephen S. Chandler, was "either unwilling or unable" to perform his judicial functions adequately. It therefore ordered that Judge Chandler be assigned no more cases and take no further action in cases pending before him. It based its action on section 332 of the Judicial Code, which gives a judicial council authority to "make all necessary orders for the effective and expeditious administration of the business of the courts within its circuit." That same section also enjoins all district courts to obey the orders of the circuit council. ${ }^{78}$

On February 28, Ig68, Senator Tydings introduced the Judicial Reform Act, ${ }^{\text {70 }}$ and on April 28, I968, he commenced more hearings. ${ }^{80}$ In discussing the bill, Senator Tydings referred again to the case of Judge Chandler as evidence that the con-

\footnotetext{
${ }^{75}$ Hearings on the Judicial Conference of the United States and the Judicial Councils of the Circtits and the Independence of Federal ludges Before the Subcomm. on Separation of Powers of the Senate Comm. on the Judiciary, 9 Ist Cong., 2d Sess. I (Apr. 7, 1970).

78 II6 Cong. Rec. S5372 (daily ed. April 8, 1970).

77 ig66 Hearings, supra note 3 , at $\mathrm{r}$.

${ }^{78}$ Id. at 2.

${ }^{70}$ S. 3055 , 9oth Cong., 2d Sess. (1968).

${ }^{80}$ Hearings on $S .3055$ Before the Subcomm. on Improvements in Judicial Machinery of the Senate Comm. on the Judiciary, 9oth Cong., 2d Sess. (1968) [hereinafter cited as 1968 Hearings]; See also 56 A.B.A.J. 373 (1970) (resolution approving federal legislation to remove federal judges for lack of good behavior).
} 
stitutional impeachment procedures do not work because there is a "gap" between the good behavior requirement for judicial tenure and the Constitution's "high Crimes and Misdemeanors" impeachment conditions. His proposal would have created a Commission on Judicial Disabilities and Tenure, with powers to recommend the removal of federal judges. ${ }^{81}$ Congress did not act on it.

In I969, Senator Tydings reported that during the previous Congress his subcommittee had fifty-five bills before it dealing with various phases of judicial administration, and was authorized to hold even more hearings. ${ }^{82}$ So more hearings were held before the subcommittee on June 7 , 1969, on the proposed five-judge commission on judicial disabilities and tenure empowered to determine whether a federal judge's conduct is consistent with the good behavior tenure requirement of article III, subject to review by the Judicial Conference of the United States and to review by writ of certiorari to the Supreme Court of the United States. ${ }^{83}$

In the meantime, the Chandler case, purportedly a precipitating cause for the renewed efforts to legislate control over good behavior, was disposed of by the Supreme Court. While the case left the question of legislative control of good behavior unresolved, it did contain some judicial views on the problem. Chief Justice Burger, who wrote the majority opinion, discussed various acts of Congress which authorize judicial councils to exercise certain administrative powers over the flow of cases through the federal court system. ${ }^{84}$ He spoke of the "line defining the maximum permissible intervention consistent with the constitutional requirement of judicial independence." ${ }^{85} \mathrm{He}$ impliedly suggested that there can be no legislative control of good behavior:

There can, of course, be no disagreement among us as to the imperative need for total and absolute independence of judges in deciding cases or in any phase of the decisional function. ... The question is whether Congress can vest in the Judicial Council power to enforce reasonable standards as to when and where court shall be held, how long a case may be delayed in decision, whether a given case is to be tried, and many other routine matters. ${ }^{86}$

\footnotetext{
${ }^{81}$ rg68 Hearings, stpra note 79, at I8. On August 7, 1970, Senator Birch Bayh introduced S. 420I, the Judical Disqualification Act. The bill attempts to legislatively determine when a judge should disqualify himself from sitting on a particular case, and authorizes each litigant one "preemptory challenge" of a trial judge. Proposals such as this intend to avoid the "appearance of impropriety" that serve to foster disrespect of the judiciary, and are another example of legislative oversight of good behavior.

${ }^{82}$ Study of Federai Judicial System, S. Rep. No. 9r-64, 9ist Cong., ist Sess. (1969).

s3 1969 Hearings, stspra note 18 , at 116 .

8428 U.S.C. \$ I37. See also Judicial, Conference of the United States, Report on the Powers and Responstbilities of tFe Judicial Councils, H.R. Doc. No. 20x, 87th Cong., ist Sess. (ig6r), reciting the legislative history of councils, the background of 28 U.S.C. $\$ 332$, and the statement of Judge Parker that "the councils will be restrained by the inherent limitations of the situation. They would know that, if they commanded a judge to do something, unnecessarily, he would refuse to do it, and that would probably be the end of the matter."

${ }^{85}$ Chandler v. Judicial Council, 398 U.S. 74, 84 (I970).

${ }^{80} 398$ U.S. at 84 .
} 
None of the language used in the several Chandler opinions suggests that Congress can legislate a commission to determine whether a federal judge is lacking in good behavior.

Justice Hugo Black issued a fiery dissent which bears importantly on the question of legislative control of good behavior:

I wish to add a few words to emphasize once again the gravity of the unconstitutional wrong the Court is inflicting upon United States District Judge Stephen Chandler, and more importantly on our system of government and the Constitution itself. The preparation and adoption of that great document was a turning point in the history of this country and of the world. Our Constitution gave new hope and dreams for freedom and equal justice... . One of the many factors which gave birth to these new dreams and hopes was our constitutional plan for a more independent judicial system than had ever before existed. Judges in our system were to hold their offices during "good Behavior," their compensation was not to be "diminished during their Continuance in Office," and they were to be removed only after impeachment and trial by the United States Congress. While judges, like other people, can be tried, convicted, and punished for crimes, no word, phrase, clause, sentence, or even the Constitution taken as a whole, gives any indication that any judge was ever to be partly disqualified or wholly removed from office except by the admittedly difficult method of impeachment by the House of Representatives and conviction by the entire Senate. Such was the written guarantee in our Constitution of the independence of the judiciary .... ${ }^{87}$

Justice Black explained in his dissent that the action of the Judicial Council deprived Judge Chandler of the full power of his office and was in effect finding that he was unfit. His dissent in this case paralleled his dissent in an earlier case involving the same judicial council and Judge Chandler when the Justice said:

The Council states that the order was made "pursuant to the powers and authority vested in the Judicial Council by . . 28 U.S.C. $\$ 332 . "$. . There is no language whatever in this or any other Act which can by any reasonable interpretation be read as giving the Council a power to pass upon the work of district judges, declare them inefficient and strip them of their power to act as judges. ${ }^{88}$

Proponents of the view that we need legislative control of good behavior sometimes imply that litigants and other citizens are at the mercy of unfit judges-and that the judicial machinery provided by the Constitution is not adequate to protect the public from these so-called unfit judges. Nothing could be further from the fact. Article III of the Constitution confers appellate jurisdiction on the Supreme Court and authorizes Congress to establish inferior courts. All actions by judges on the merits of litigation are appealable to the Courts of Appeals, ${ }^{80}$ and any impropriety or alleged unfitness of a federal trial judge may be challenged at

\footnotetext{
${ }^{87} 398$ U.S. at $14 \mathrm{I}-42$.

${ }^{88}$ Chandler v. Judicial Council, 382 U.S. 1003, 1005 (1966).

${ }^{80} 28$ U.S.C. $\$ 43$ (a) (1964).
} 
any time under the procedures of the All Writs Act. ${ }^{90}$ A litigant who thinks he is confronted in a trial with an unfit judge can file an affidavit of personal prejudice. ${ }^{91}$ A successor judge can be designated, or trial judges can disqualify themselves. ${ }^{92}$ In trials on the merits, appeals may be taken as to certain interlocutory orders. ${ }^{93}$ An unfit judge is subject to criminal laws covering bribery, graft, and conflicts of interest. $^{04}$ If a judge is unable to perform his duties, the district judge in active service next in seniority takes over. ${ }^{95}$ A judge who attempts to practice law is guilty of a high misdemeanor. ${ }^{96}$ Judges are required to disqualify themselves in cases where they have a personal interest, have acted as a lawyer or material witness, or are so related to or connected with any party or his attorney as to make it improper for the judge to sit on the trial, appeal, or any other phase of a proceeding. ${ }^{97}$ A judge is prohibited from employing any of his relatives related within the degree of first cousin. .8 Judges are required to take an oath to "Administer justice without respect to persons and do equal right to the poor and to the rich, and ... faithfully and impartially discharge and perform all the duties" of their office. ${ }^{99}$ In short, under proper constitutional authority, Congress has provided adequate and comprehensive procedures to protect the public interest and the integrity of judicial positions from the unfit judge or a judge who fails to meet the standard of good behavior under which he is bound by the federal Constitution, until he can be impeached.

If a judgeship becomes vacant for any reason, including unfitness, unavailability, or for any other reason, Congress has provided for the clerk of the court to continue all pending matters until a judge is appointed or designated to hold the court involved. ${ }^{100}$ A federal judge may resign at the age of seventy and continue to receive a full salary for the remainder of his life term, or retire at age seventy, but retain office at full salary with the President appointing a successor judge to carry on the duties of the office. ${ }^{101}$ In addition, the President can appoint another judge to perform the duties of a disabled judge. ${ }^{102}$ These statutory provisions protect the integrity of the judicial process, but do not do so by determining the good behavior of the judge.

The clear lesson of experience, and such judicial language as there is, is that legislative control of good behavior other than through impeachment is precluded

\footnotetext{
${ }^{00} 28$ U.S.C. $\S 165 I(1964)$.

${ }^{01} 28$ U.S.C. $\$ 144$ (I964).

${ }^{03} 28$ U.S.C. $\$ \$ 292(a), 455$ ( 1964$)$.

${ }^{03} 28$ U.S.C. \$ I29I (1964).

${ }^{04} \mathrm{I} 8$ U.S.C. $\S \S 201$, et seq. (1964).

${ }^{05} 28$ U.S.C. $\$ 132$ ( 1964$)$.

${ }^{00} 28$ U.S.C. $\$ 454(1964)$.

${ }^{87} 28$ U.S.C. $\$ 455$ (1964).

${ }^{08} 28$ U.S.C. $\$ 458$ (1964).

${ }^{00} 28$ U.S.C. $\$ 453(\mathrm{Ig} 64)$.

${ }^{100} 28$ U.S.C. \$ I 43 (I964).

${ }_{101} 28$ U.S.C. $\$ 37$ Ia)-(b) (1964).

${ }^{102} 28$ U.S.C. $\$ 382$ (I964).
} 
by the provisions of the Constitution. The Chandler case is an example of where the problem lies. When is legislative control of administrative details an attempt at legislative control of good behavior in violation of the Constitution? A House Judiciary Committee preliminary report of April $3^{0}$, 1968, although not formally adopted, had some interesting conclusions on legislative control of good behavior in the same case:

The action of the Tenth Circuit Judicial Council on December 13 , x96I to strip Judge Chandler of his power to hear cases was equivalent to his removal as a judge. It was an action completely beyond the legal authority of the Council. Such action is forbidden by the Constitution. ${ }^{103}$

Some proponents of legislative control of good behavior point to the statute enacted in 1790 by the first Congress making it a crime for a judge to accept a bribe, and barring a convicted judge from office, as an indication that a non-exclusive interpretation of the impeachment clause was intended. It seems rather that this simply indicates that impeachable offenses are additionally punishable as crimes. This is underlined by the fact that "bribery" as such is specifically named as an impeachable offense in the Constitution. This statute continues in force, but no court has ever viewed it as a method of legislative control over good behavior. ${ }^{104}$

\section{ConcLusion}

This article has outlined in a general way some of the considerations that entered into the thinking of the men who wrote the federal Constitution respecting the importance of maintaining an independent federal judiciary. In considering the constitutionality of more legislative controls over good behavior, we should bear in mind not only the words of the federal Constitution, but the debates and writings of the authors of that great document.

A catalogue of existing statutes supplement the impeachment procedures of the the federal Constitution and give every reasonable protection to litigants and to the judicial system against unfit judges. They insure that the business of the courts can proceed uninterrupted by the activities of an unfit judge. However, these statutory provisions, like the impeachment procedures of the federal Constitution, do not authorize any administrative body or any other judge to supervise or interfere in the day to day work of a federal trial judge in the conduct of his office. In short, these statutes and the federal Constitution assure the independence of the federal judiciary, while at the same time, providing methods for protecting the public from

\footnotetext{
${ }^{103}$ I968 REPORT, supra note 8, at 74 .

${ }^{104}$ I8 U.S.C. $\$ 201$ (1964) (Act of April 30, r790, ch. IX, $\S 2 \mathrm{r}$, I Stat. $1 \times 7$, cited in debates in Congress in I94I on H.R. 146 as a justification for proposed legislative control of good behavior). The law was later incorporated in the Revised Statutes, the Criminal Code of 1909, the 1948 enactment of 18 U.S.C. into positive law, and the 1962 revision of the Bribery and Conflict of Interest provisions of title I8. It is no doubt unconstitutional unless invoked after convicting a judge by the Senate on impeachment by the House.
} 
an unfit judge until the constitutional removal procedures can be invoked. They also provide a method of appealing both on an interlocutory basis and on the merits from what are thought to be the wrong decisions of federal trial judges. We have as near perfect a guarantee of fair and impartial trials by independent judges as human frailty can devise.

When one reviews the history and the actions of the founding fathers at the time they provided for federal judges' tenure of office to be measured only by "good Behaviour" and the "sole" method of removal to be by impeachment and trial in a special impeachment court made up of members of the United States Senate, there can be no other conclusion but that attempted legislative control of good behavior is unconstitutional and in conflict with the basic principles of an independent federal judiciary. Legislative controls over administrative details of the office of a federal judge and over the flow of cases through the judicial system are constitutionally permissible, but beyond that, Congress can not go. 